\title{
Perlakuan Biaya Pendidikan dan Pelatihan pada Balai Diklat Keuangan Balikpapan : Pendekatan Activity Based Costing
}

\author{
Ade Lista ${ }^{1}$, Miswaty ${ }^{2}$ \\ ${ }^{1,2}$ Fakultas Ekonomi (Akuntansi, Universitas Balikpapan), Jl. Pupuk Raya Balikpapan, Indonesia, 76114 \\ Correspondence: Miswaty (miswaty@yahoo.co.id) \\ Received: 090821 - Revised: 100821 - Accepted: 100821 - Published: 280921
}

\begin{abstract}
Abstrak. Balai Diklat Keuangan Balikpapan adalah salah satu unit vertikal yang berada di bawah Badan Pendidikan dan Pelatihan Keuangan yang memiliki tugas dan fungsi melaksanakan pendidikan dan pelatihan bagi Aparatur Sipil Negara (ASN) Kementerian Keuangan melalui pendidikan dan pelatihan keuangan negara di daerah, dengan wilayah kerja yaitu Kalimantan Timur, Kalimantan Utara, dan Kalimantan Selatan. Pada tahun 2019, pada tahun 2019 mengelola Daftar Isian Pelaksanaan Anggaran (DIPA) sebesar Rp10.515.220.000. Data realisasi dan capaian penyerapan DIPA pada Balai Diklat Keuangan Balikpapan sampai dengan akhir tahun anggaran 2019 yaitu sebesar Rp10.152.079.589. Pada tahun 2019 Balai Diklat Keuangan Balikpapan telah menyelenggarakan sebanyak 27 pelatihan dengan realisasi peserta sebanyak 956 peserta. Salah satu pelatihan yang diselenggarakan adalah Pelatihan Dasar (Latsar) CPNS Golongan II Periode II dengan rencana peserta 60 orang dan realisasi peserta sebanyak 59 orang atau sebesar 98,33\%.

Terdapat perbedaan hasil perhitungan ABC System dengan Standar Biaya yang digunakan oleh Balai Diklat Keuangan Balikpapan. Perbedaan perhitungan terjadi karena dalam perhitungan sesuai Standar Biaya hanya menghitung biaya yang terkait secara langsung dengan diklat saja yaitu untuk komponen Direct Material dan Direct Labor, sedangkan perhitungan berdasarkan Activity Based Costing System menghitung seluruh biaya yang terkait dengan diklat yang berupa direct material, direct labor, dan factory overhead. Dengan demikian selisih diantara keduanya adalah senilai factory overhead.
\end{abstract}

Kata kunci: Biaya pendidikan dan pelatihan, Activity Based Costing System

Citation Format: Lista, A., Miswaty. (2020). Perlakuan Biaya Pendidikan dan Pelatihan pada Balai Diklat Keuangan Balikpapan : Pendekatan Activity Based Costing. Prosiding Seminar Nasional Abdimas Ma Chung (SENAM), 2020, 30-42 


\section{PENDAHULUAN}

Pada suatu organisasi perlu adanya praktik manajerial yang baik dan mendukung tujuan dari organisasi perlu adanya akuntansi manajemen dalam melakukan pengawasan dan pengendalian terhadap unsur-unsur yang berhubungan langsung dalam proses mencapai tujuan dari organisasi. Akuntansi manajemen merupakan suatu kegiatan atau proses yang menghasilkan informasi keunagan bagi manajemen untuk pengambilan keputusan ekonomi dalam melaksanakan fungsi manajemen (Indriani, 2018). Pengendalian dalam akuntansi manajemen meliputi penyusunan anggaran, pelaksana rencana, pemantauan kinerja, mengevaluasi kinerja serta memperbaiki pengendalian terhadap hal yang terjadi di luar situasi. Pada proses pengendalian tidak terlepas dari kebutuhan akan sistem informasi akuntansi manajemen yang baik. Inti dari sistem informasi akuntansi manajemen adalah proses yang dideskripsikan oleh aktivitas-aktivitas seperti pengumpulan, pengukuran, penyimpanan, analisis, pelaporan, dan pengelolaan informasi mengenai peristiwa-peristiwa ekonomi yang akan menghasilkan output tertentu untuk memenuhi tujuan sistem yang diharapkan (Amrullah, 2014). Output tersebut dapat mencakup laporan khusus, biaya pelanggan, anggaran, laporan kinerja, dan informasi yang sangat penting dalam posisi tawar sebuah organisasi akan produknya yaitu biaya produksi per unit (unit cost of production).

Kemampuan menganalisis data biaya produk juga berfungsi sebagai alat untuk pengambilan keputusan manajemen. Untuk Untuk mewujudkannya, metode analisis biaya yang tepat perlu diterapkan di Indonesia. ABC adalah metode alternatif yang direkomendasikan untuk digunakan di sektor publik oleh, misalnya, Michel (2004), Cai et al. (2013), dan Cokins (2015). Salah satu hal yang menjadi penting untuk dianalisis yaitu perhitungan biaya manfaat jasa dan pelayanan yang diberikan sektor publik kepada para pengguna jasa (stakeholder). Dengan mengetahui biaya jasa dan layanan tersebut dapat membantu pihak manajemen dalam mengambil keputusan salah satunya mengenai biaya yang digunakan oleh organisasi dalam menghasilkan output dan outcome yang efektif dan efisien. Salah satu pendekatan dalam menghitung besarnya biaya adalah dengan activity based costing system.

Perhitungan activity based costing system dapat diterapkan pada semua bidang usaha, termasuk bidang pelayanan jasa. Salah satu yang dapat diteliti dengan menggunakan activity based costing system pada bidang pelayanan jasa adalah perhitungan jasa tarif rawat inap pada rumah sakit. Hasil penelitian yang pernah dilakukan menjelaskan terdapat perbedaan tarif jasa pada beberapa kelas ruang rawat inap pada rumah sakit tersebut, perbedaan tarif 
tersebut dikarenakan pembebanan biaya overhead pada masing-masing produk dari masingmasing metode. Biaya overhead pada Activity Based Costing System (ABC System) dibebankan pada banyak cost driver, sehingga pengalokasian biaya aktivitas kesetiap kamar sudah tepat berdasarkan konsumsi masing-masing aktivitas (Anggraini, 2013).

Penelitian dengan menggunakan metode Activity Based Costing System (ABC System) juga dapat diterapkan pada bidang pelayanan jasa sektor pemerintahan. Penelitian yang telah dilakukan menjelaskan bahwa terdapat perbedaan hasil perhitungan Activity Based Costing System (ABC System) dengan standar biaya yang digunakan oleh instansi tersebut. Hal itu dikarenakan standar biaya yang digunakan oleh instansi tersebut hanya menghitung biaya yang terkait secara langsung. Sedangkan Activity Based Costing System (ABC System) menghitung seluruh biaya yang berkaitan yang berupa direct material, direct labor, dan factory overhead (Amrullah dan Kisworo, 2014). Penelitian serupa dilakukan oleh TN., M. Rizki (2015), dengan menggunakan data sekunder yang berbeda dengan Amrullah dan Kisworo (2015), hasil yang diperoleh sama dengan penelitian Amrullah dan Kisworo (2015). Akan tetapi pada penelitian TN., M. Rizki (2015), banyak beban-beban dan aktivitas yang bersifat overhead tidak diperhitungkan, sehingga dapat menimbulkan bias dalam perhitungannya.

Penerapan perhitungan biaya pada Balai Diklat Keuangan Balikpapan mengacu pada Satuan Biaya Masukan (SBM) Kementerian Keuangan seperti yang diatur dalam Peraturan Menteri Keuangan Nomor 32/PMK.02/2018, biaya lainnya yang belum tercantum dalam SBM Kementerian Keuangan, maka mengacu pada Satuan Biaya Masukan Lainnya (SBML) Badan Pendidikan dan Pelatihan Keuangan (BPPK) pada tahun terkait. Dalam SBM maupun SBML tidak merincikan biaya persatuan output contohnya biaya untuk setiap peserta diklat. Pada SBM dan SBML hanya terdapat biaya untuk setiap kelas diklat atau hanya untuk setiap diklat. Oleh karena itu, analisis biaya berdasarkan data biaya aktual diperlukan untuk menghitung biaya layanan pemerintah dengan produk sebagai serta untuk mendapatkan informasi tentang proses bisnis untuk organisasi pengelolaan.

Berdasarkan pengertian activity based costing system, latar belakang masalah, dan penelitian sebelumnya, serta tidak tercantumnya biaya rinci untuk peserta pendidikan dan pelatihan di dalam Satuan Biaya Masukan (SBM) dan Satuan Biaya Masukan Lainnya (SBML), maka penelitian ini memfokuskan pada analisis perhitungan biaya Pendidikan dan Pelatihan Dasar CPNS Golongan II Periode II Tahun Anggaran 2019 pada Balai Diklat 
Keuangan Balikpapan. Kemudian membandingkan dengan perhitungan menggunakan metode activity based costing system.

\section{METODE PELAKSANAAN}

Objek penelitian adalah Realisasi Anggaran Balai Pendidikan dan Pelatihan Keuangan Balikpapan Tahun Anggaran 2019 dalam rangka menghasilkan jumlah output peserta pendidikan dan pelatihan keuangan. Lokasi penelitian adalah satuan kerja Balai Diklat Keuangan Balikpapan dengan alamat Jalan MT. Haryono Dalam Nomor 97 RT. 40, Kelurahan Gunung Bahagia, Kecamatan Balikpapan Selatan.

Metode analisis data yang digunakan dalam penyusunan penilitian ini adalah metode analisis kuantitatif deskriptif. Langkah-langkah yang dilakukan dalam penulisan penelitian ini adalah dengan melakukan analisis biaya pelatihan pada Laporan Realisasi Anggaran.

Selanjutnya penulis menetapkan metode biaya berdasarkan activity based costing dengan langkah-langkah sebagai berikut:

i. Mengidentifikasi biaya dan aktivitas sumber daya. Langkah pertama dalam merancang activity based costing system, adalah melakukan analisis aktivitas untuk mengidentifikasi biaya sumber daya dan aktivitas perusahaan. mengidentifikasi dan memproporsikan biaya kelompok aktivitas ke dalam kategori tahapan aktivitas yang terdiri dari tahap persiapan, tahap pelaksanaan, dan tahap penilaian kompetensi.

ii. Mengidentifikasi dan memproporsikan biaya tahap delivery berdasarkan keterkaitannya dengan produk. Biaya manufaktur atau biaya produksi didefinisikan sebagai hasil penjumlahan dari 3 elemen biaya yaitu biaya bahan langsung (direct materials), biaya tenaga kerja langsung (direct labor) dan biaya overhead (factory overhead). Dalam kajian akademis ini, hasil penjumlahan direct materials dan direct labor disebut dengan biaya langsung, sedangkan factory overhead disebut dengan biaya tidak langsung. Setelah diketahui biaya langsung dan biaya tidak langsung, maka biaya per output peserta diklat dapat dihitung.

iii. Dengan melakukan langkah pada poin 2 maka dapat diketahui biaya pelatihan perpeserta pelatihan berdasarkan perhitungan activity based costing.

Membandingkan biaya pelatihan berdasarkan ABC dengan Standar Biaya. 


\section{HASIL DAN PEMBAHASAN}

Balai Diklat Keuangan Balikpapan adalah salah satu unit eselon III yang berada dibawah lingkungan Badan Pendidikan dan Pelatihan Keuangan yang memiliki tugas dan fungsi melaksanakan pendidikan dan pelatihan bagi Aparatur Sipil Negara (ASN) Kementerian Keuangan melalui pendidikan dan pelatihan keuangan negara di daerah, dengan wilayah kerja yaitu Kalimantan Timur, Kalimantan Utara, dan Kalimantan Selatan.

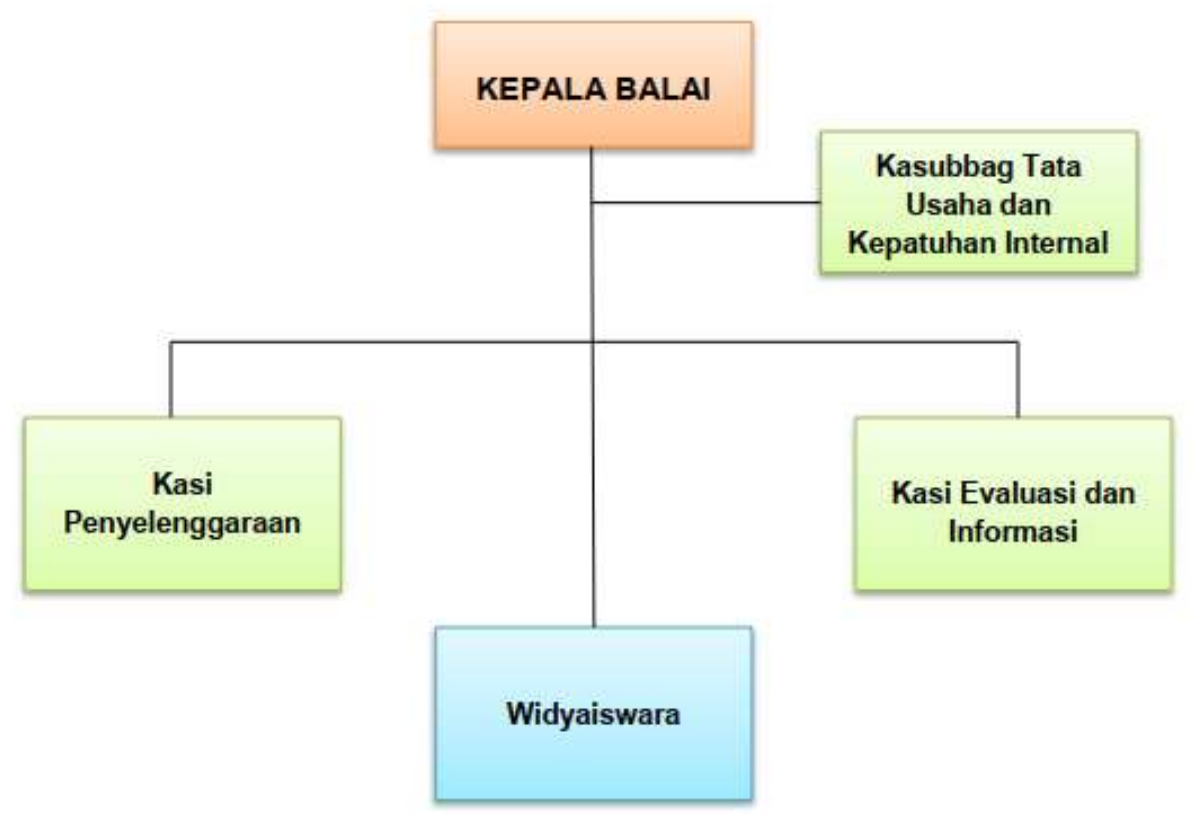

Gambar 1. Struktur Anggaran Balai Diklat Keuangan

Sumber : Laporan Kinerja Balai Diklat Keuangan Balikpapan

Dalam menjalankan tugas dan fungsinya, Balai Diklat Keuangan Balikpapan pada tahun 2019 mengelola Daftar Isian Pelaksanaan Anggaran (DIPA) sebesar Rp10.515.220.000. Data realisasi dan capaian penyerapan DIPA pada Balai Diklat Keuangan Balikpapan sampai dengan akhir tahun anggaran 2019 yaitu sebesar Rp10.152.079.589 dengan capaian sebesar 96,54\%.

Pada tahun 2019 Balai Diklat Keuangan Balikpapan telah menyelenggarakan sebanyak 27 pelatihan dengan realisasi peserta sebanyak 956 peserta. Salah satu pelatihan yang diselenggarakan adalah Pelatihan Dasar (Latsar) CPNS Golongan II Periode II dengan rencana peserta 60 orang dan realisasi peserta sebanyak 59 orang atau sebesar 98,33\%. Dalam penganggaraanya, anggaran terkait jumlah peserta diklat dibagi kedalam tiga golongan belanja, yakni belanja terkait tahapan persiapan diklat, tahapan pelaksanaan diklat, 
dan tahapan evaluasi diklat. Belanja terkait tahapan persiapan diklat adalah belanja yang muncul ketika persiapan diklat dilaksanakan atau dengan kata lain ketika diklat belum berjalan. Contoh belanja tahapan persiapan diklat adalah belanja ATK peserta dan ATK penyelenggaran, pencetakan modul atau bahan ajar, seragam peserta diklat, perlengkapan asrama peserta diklat, dan rapat persiapan diklat.

Belanja dalam tahapan pelaksanaan diklat atau tahap pelayanan kelas adalah belanja yang dilakukan ketika diklat sedang berjalan dan ditujukan untuk memenuhi kebutuhan pelaksanaan diklat dan pelayanan diklat kepada para peserta diklat. Belanja terkait tahap pelaksanaan diklat adalah belanja dengan jumlah paling besar dibandingkan dengan dua tahapan yang lainnya. Jenis belanja yang muncul terkait tahapan pelaksanaan diklat adalah belanja konsumsi peserta, belanja terkait pelayanan laundry, honorarium atas pengajar, penceramah, asisten pengajar, pelatih, tenaga kesehatan, petugas piket, dan biaya terkait perjalan dinas peserta dan pengajar.

Belanja dalam tahapan evaluasi diklat atau tahap penilaian kompetensi adalah belanja yang dikeluarkan ketika diklat akan selesai atau telah selesai. Belanja ini merupakan belanja dengan proporsi terkecil dibandingkan dengan tahapan belanja lainnya. Contoh dari belanja ini adalah belanja konsumsi rapat evaluasi.

\section{Perhitungan Biaya}

\section{Tahapan Aktivitas}

a. Tahap Persiapan

Biaya Perencanaan diklat dalam Standar Biaya hanya terkait dengan aktivitas persiapan pelaksanaan suatu diklat tertentu dari sifatnya berulang, selalu dikeluarkan sebelum diklat dimulai.

b. Tahap Pelaksanaan

Biaya Pelaksanaan diklat merupakan biaya yang dikeluarkan saat diklat sudah mulai dijalankan, sifatnya berulang dan spesifik untuk satu diklat tertentu.

c. Tahap Evaluasi

Evaluasi merupakan biaya untuk melakukan evaluasi penyelenggaraan, peserta, dan pengajar suatu diklat pada tahun anggaran tersebut. Sifatnya berulang dan spesifik untuk satu diklat tertentu 
Anggaran belanja barang ditambah dengan besaran belanja pegawai yang terpakai untuk melakukan aktivitas dibagi dan dikategorikan kepada tahapan aktivitas. Biaya Pelatihan Dasar CPNS pada Laporan Realisasi Anggaran merupakan biaya keseluruhan angkatan diklat yang terdapat pada Pagu DIPA Laporan Realisasi Anggaran. Pelatihan Dasar CPNS Tahun Anggaran 2019 pada Balai Diklat Keuangan Balikpapan terdiri dari 4 Angkatan yaitu Pelatihan Dasar CPNS Golongan II Periode II, Pelatihan Dasar CPNS Golongan II Periode III, Pelatihan Dasar CPNS Golongan II Periode IV, dan Pelatihan Dasar CPNS Golongan II Periode V. Biaya Pelatihan Dasar CPNS (untuk 1 Angkatan Pelatihan) diasumsikan memiliki besaran yang sama dalam setiap angkatan pelatihan, maka biaya per angkatan pelatihan diperoleh dari Biaya Pelatihan Dasar CPNS pada Laporan Realisasi Anggaran dibagi empat, sehingga biaya untuk tahap persiapan per-angkatan pelatihan adalah sebesar Rp33.837.750, tahap pelaksanaan sebesar Rp693.667.250, dan tahap penilaian kompetensi sebesar Rp212.750.

Biaya Pelatihan Dasar CPNS untuk 1 Angkatan Diklat (dalam penelitian) diperoleh dari hasil pembagian biaya realisasi anggaran pada Laporan Realisasi Anggaran. Tahap persiapan sebesar Rp116.250, tahap pelaksanaan sebesar Rp668.109.227, dan tahap penilaian kompetensi tidak ada biaya yang dikerluarkan, hal ini karena tidak adanya biaya yang dikeluarkan pada saat penilaian kompetensi.Dari Gambar 4 dapat disimpulkan bahwa biaya yang paling besar adalah biaya Tahap Pelaksanaan yaitu sebesar Rp668.109.227 $(99,98 \%)$.

Tabel 1. Perbandingan Biaya per Angkatan Diklat

\begin{tabular}{llll}
\hline $\begin{array}{l}\text { Pembagian Biaya } \\
\text { Berdasarkan } \\
\text { Aktivitas }\end{array}$ & $\begin{array}{l}\text { Biaya Pelatihan } \\
\text { Dasar CPNS }\end{array}$ & $\begin{array}{l}\text { Biaya Pelatihan } \\
\text { Dasar CPNS } \\
\text { (untuk 1 } \\
\text { Angkatan } \\
\text { Pelatihan) }\end{array}$ & $\begin{array}{l}\text { Biaya Pelatihan } \\
\text { Dasar CPNS untuk } \\
\text { 1 Angkatan Diklat } \\
\text { (dalam penelitian) }\end{array}$ \\
\hline $\begin{array}{l}\text { Tahap Persiapan } \\
\text { Tahap Pelaksanaan }\end{array}$ & Rp135.351.000 & Rp33.837.750 & Rp116.250 \\
$\begin{array}{l}\text { Tahap Penilaian } \\
\text { Kompetensi }\end{array}$ & Rp851.000 & Rp212.750 & \\
\hline
\end{tabular}

Sumber : Data Diolah Dari Laporan Realisasi Anggaran

\section{Keterkaitan biaya dengan produk}

Berdasarkan keterkaitannya dengan produk, biaya dapat dikategorikan menjadi biaya langsung (prime cost) dan biaya tidak langsung (convertion cost). Biaya langsung yaitu berupa biaya bahan baku langsung (Direct Material) dan biaya tenaga kerja langsung (Direct Labor) sedangkan biaya tidak langsung berupa Factory Overhead (FOH). 
Tabel 2. Deskripsi dan Contoh Biaya

\begin{tabular}{|c|c|c|c|}
\hline No. & $\begin{array}{c}\text { Kategori } \\
\text { Biaya }\end{array}$ & Uraian & Contoh Biaya \\
\hline \multirow[t]{5}{*}{1.} & Direct & Merupakan biaya operasional yang & Biaya konsumsi \\
\hline & Material & dikeluarkan untuk penyelenggaraan & peserta diklat, \\
\hline & & diklat. Nilainya akan semakin & penggandaan modul, \\
\hline & & bertambah dengan mengikuti & laundry, atk dan \\
\hline & & penambahan jumlah peserta diklat. & perlengkapan peserta \\
\hline \multirow[t]{6}{*}{2.} & Direct & Merupakan biaya yang dikeluarkan & Honor narasumber, \\
\hline & Labor & untuk membayar tenaga atau jasa & pengajar, honor \\
\hline & & seseorang terkait dengan & petugas piket, honor \\
\hline & & penyelenggaraan diklat. & instruktur, atk \\
\hline & & & penyelenggaraan \\
\hline & & & konsumsi rapat \\
\hline \multirow[t]{6}{*}{3.} & Factory & Merupakan biaya yang tidak terkait & Belanja pegawai, \\
\hline & Overhead & langsung dengan penyelenggaraan & biaya operasional \\
\hline & & diklat dan nilainya cenderang tetap & perkantoran, honor \\
\hline & & walaupun terdapat penambahan & satpam, cleaning \\
\hline & & jumlah peserta dan angkatan diklat. & Service, pramugraha, \\
\hline & & & beban penyusutan \\
\hline
\end{tabular}

Berikut ini adalah Gambar 1 yang menggambarkan biaya berdasarkan keterkaitannya dengan produk (peserta diklat) pada Pelatihan Dasar CPNS Golongan II Periode II yang diselenggarakan oleh Balai Diklat Keuangan Balikpapan: 
Gambar 2. Perbandingan Keterkaitan Biaya dengan Produk

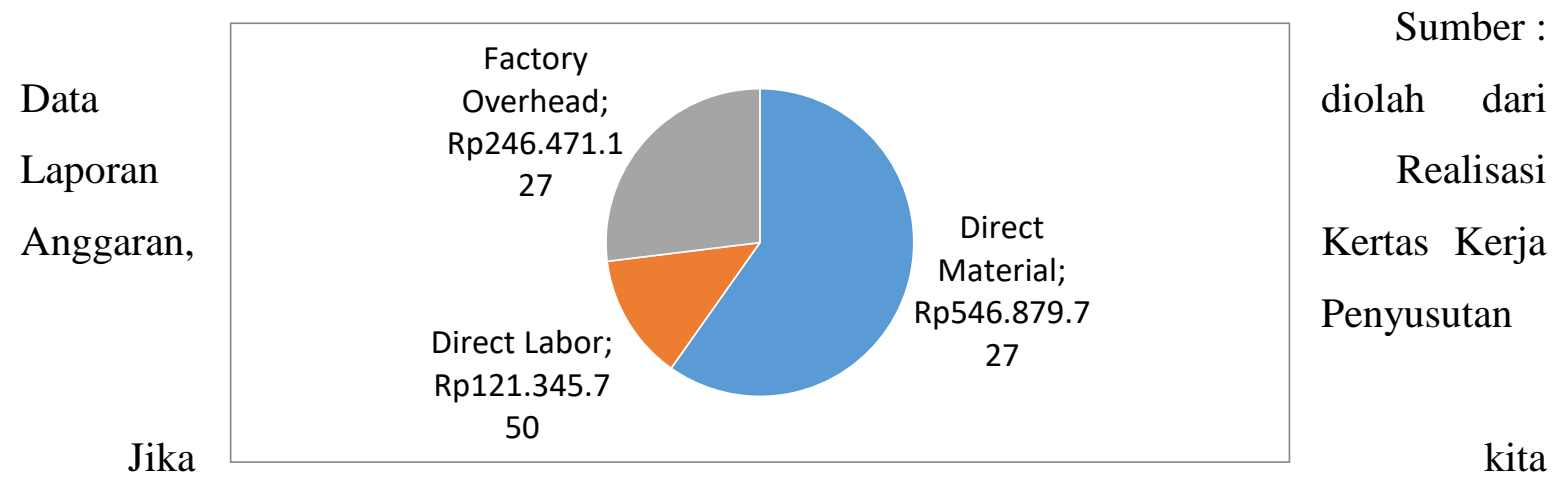

perhatikan Gambar 1 dapat kita ketahui bahwa komposisi terbesar dari biaya yang dikeluarkan oleh Balai Diklat Keuangan Balikpapan adalah berupa Direct Material yaitu sebesar Rp546.879.727 (60\%) sedangkan Direct Labor sebesar Rp121.345.730 (13\%) dan Factory Overhead sebesar Rp246471127 (27\%). Pengkategorian berdasarkan keterkaitannya dengan produk akan bermanfaat bagi suatu satuan kerja untuk mengenali biaya-biaya yang dikeluarkan bila dikaitkan dengan produknya. Semakin mudah mengkaitkan biaya yang dikeluarkan dengan produk (jumlah peserta pelatihan), maka akan semakin mudah untuk menyusun standar biaya per out peserta pelatihan (Amrullah dan Kisworo, 2014).

Data biaya per-peserta pelatihan diperoleh dari biaya direct material, direct labor, dan factory ovehead dibagi dengan jumlah realisasi peserta Pelatihan Dasar CPNS Golongan II Periode II yaitu sebanyak 59 peserta, dengan lama pelaksanaan pelatihan selama 23 hari maka biaya per-peserta yang diperoleh adalah $\mathrm{Rp} 15.503 .332$.

Tabel 3. Komposisi direct material, direct labor dan factory overhead per-peserta pelatihan

\begin{tabular}{cccc}
\hline Nama Pelatihan & Direct Material & Direct Labour & Factory Overhead \\
\hline Pelatihan Dasar CPNS & Rp9.269.148 & Rp2.056.708 & Rp4.177.477
\end{tabular}

Golongan II Periode II

\section{Sumber: data diolah}

Berdasarkan pengolahan data, biaya yang dibutuhkan per-peserta diklat sesuai $\mathrm{ABC}$ Sistem menghasilkan perhitungan biaya yang berbeda dengan perhitungan biaya menggunakan Standar Biaya. Perbedaan tersebut dapat digambarkan dalam Tabel sebagai berikut:

Tabel 4. Perbedaan Biaya Sesuai ABC Sistem dan Sesuai Standar Biaya 


\begin{tabular}{cccc}
\hline Nama Pelatihan & $\begin{array}{c}\text { Biaya Per-peserta } \\
\text { Diklat sesuai ABC } \\
\text { Sistem }\end{array}$ & $\begin{array}{c}\text { Biaya Per-peserta } \\
\text { Diklat sesuai Standar } \\
\text { Biaya }\end{array}$ & Selisih \\
\hline $\begin{array}{c}\text { Pelatihan Dasar } \\
\text { CPNS Golongan II } \\
\text { Periode II }\end{array}$ & Rp15.503.332 & Rp12.128.629 & Rp3.374.703 \\
\hline
\end{tabular}

Berdasarkan pengolahan data, biaya yang dibutuhkan per-peserta diklat sesuai ABC Sistem menghasilkan perhitungan biaya yang berbeda dengan perhitungan biaya menggunakan Perbedaan perhitungan terjadi karena dalam perhitungan sesuai Standar Biaya hanya menghitung biaya yang terkait secara langsung dengan pelatihan saja yaitu untuk komponen direct material dan direct labor, sedangkan perhitungan berdasarkan Activity Based Costing System menghitung seluruh biaya yang terkait dengan diklat yang berupa direct material, direct labor, dan factory overhead. Dengan demikian selisih diantara keduanya adalah senilai factory overhead.

\section{KESIMPULAN}

Balai Diklat Keuangan Balikpapan adalah salah satu unit vertikal yang berada di bawah Badan Pendidikan dan Pelatihan Keuangan yang memiliki tugas dan fungsi melaksanakan pendidikan dan pelatihan bagi Aparatur Sipil Negara (ASN) Kementerian Keuangan melalui pendidikan dan pelatihan keuangan negara di daerah, dengan wilayah kerja yaitu Kalimantan Timur, Kalimantan Utara, dan Kalimantan Selatan. Pada tahun 2019, pada tahun 2019 mengelola Daftar Isian Pelaksanaan Anggaran (DIPA) sebesar Rp10.515.220.000. Data realisasi dan capaian penyerapan DIPA pada Balai Diklat Keuangan Balikpapan sampai dengan akhir tahun anggaran 2019 yaitu sebesar Rp10.152.079.589. Pada tahun 2019 Balai Diklat Keuangan Balikpapan telah menyelenggarakan sebanyak 27 pelatihan dengan realisasi peserta sebanyak 956 peserta. Salah satu pelatihan yang diselenggarakan adalah Pelatihan Dasar (Latsar) CPNS Golongan II Periode II dengan rencana peserta 60 orang dan realisasi peserta sebanyak 59 orang atau sebesar 98,33\%. Terdapat perbedaan hasil perhitungan ABC System dengan Standar Biaya yang digunakan oleh Balai Diklat Keuangan Balikpapan. Perbedaan perhitungan terjadi karena dalam perhitungan sesuai Standar Biaya hanya menghitung biaya yang terkait secara langsung dengan diklat saja yaitu untuk komponen Direct Material dan Direct Labor, sedangkan perhitungan berdasarkan Activity Based Costing System menghitung seluruh 
biaya yang terkait dengan diklat yang berupa direct material, direct labor, dan factory overhead. Dengan demikian selisih diantara keduanya adalah senilai factory overhead.

\section{UCAPAN TERIMA KASIH}

Ucapan terima kasih ditujukan kepada semua pihak yang terlibat dalam pembuatan naskah..

\section{DAFTAR PUSTAKA}

A'isyah, F. S. (2013). Penerapan Activity Based Costing System (ABC System) Dalam Penentuan Harga Pokok Produksi (HPP) (Studi Kasus pada Perusahaan Rokok Djagung Prima Malang 2011). Jurnal Administrasi Bisnis (JAB) Vol. 2 No. $1 \mathrm{Mei}$ 2013.

Amrullah, M., dan Kisworo, J. (2014). Analisis Perilaku Biaya dan Perhitungan Biaya Per Output Pendidikan dan Pelatihan dengan Pendekatan Activity Based Costing System pada Pusdiklat Anggaran Dan Perbendaharaan Tahun Anggaran 2013. Kajian Akademis BPPK.

Andriansyah, R., Handayani, S. R., dan Azizah, D. F. (t.thn.). Penerapan Metode Activity Based Costing Dalam Penetapan Tarif Rawat Inap Pada Rumah Sakit (Studi Pada Rumah Sakit Islam Gondanglegi Malang).

Anggraini, N. (2013). Penerapan Metode Activity Based Costing System dalam Menentukan

Besarnya Tarif Jasa Rawat Inap (Studi Kasus pada RSB Nirmala, Kediri). Cendikia Akuntansi Vol. 1 No.1 - Januari 2013.

Atkinson, A. A., \& dkk. (2009). Akuntansi Manajemen. Jakarta: PT Indeks.

Carter, W. K. (2009). Cost Accounting: Akuntansi Biaya. Jakarta: Salemba Empat.

Garrison, R. H., Noreen, E. W., \& Brewer, P. C. (2006). Akuntansi Manajerial, Buku I edisi kesebelas. Jakarta: Salemba Empat.

Hansen, D. R. (2009). Akuntansi Manajemen, Edisi 8. Jakarta: Salemba 4.

Husni, A. S. (2017). Analisis Perhitungan Biaya Satuan (Unit Cost) SPP Bulanan Program Reguler dan Premium di Sekolah Bola Basket (SBB) DBL Academy Surabaya Pada Tahun 2017. Jurnal Akuntansi AKRUAL 8 (1) (2016) :28-43 e-ISSN: 2502-6380.

Indriani, E. (2018). Akuntansi Manajemen. Yogyakarta: Penerbit Andi.

Khairunnisa, A. (2015). Analisis Perbandingan Metode Tradisional dan Metode Activity Based Costing Dalam Perhitungan Unit Cost Pada PD Kebersihan Kota Bandung.

Kurniawan, W. O. (2019). Penerapan Metode ABC (Activity Based Costing) Dalam Menentukan Harga Jual Kamar Hotel "X" (Studi pada Salah Satu Hotel Berbintang di Surabaya). JEDI Vol. 2 No. 2 pp 31-42, 2019.

Mulyadi. (2007). Activity Based Costing System. Edisi Keenam. Yogyakarta: UPP STIM YKPN.

Mulyadi. (2016). Akuntansi Biaya. Yogyakarta: UPP STIM YKPN.

Priyatmo, T., \& Akbar, R. (2019). Analysis of the Prospect of Implementing Activity-Based Costing (ABC) in Governmental Organisations: A Study at the State Treasury Office Jakarta IV. Journal of Accounting and Investment, vol. 20 no. 1, January 2019, http://journal.umy.ac.id/index.php/ai.

Peraturan Menteri Keuangan Nomor 177/PMK.01/2012 Tentang Organisasi dan Tata Kerja Balai Pendidikan dan Pelatihan Keuangan

Peraturan Pemerintah Republik Indonesia Nomor 90 Tahun 2010 Tentang Penyusunan Rencana Kerja Dan Anggaran Kementerian Negara/Lembaga. 
Priyatmo, T., \& Akbar, R. (2019). Analysis of the Prospect of Implementing Activity-Based Costing (ABC) in Governmental Organisations: A Study at the State Treasury Office Jakarta IV. Journal of Accounting and Investment, vol. 20 no. 1, January 2019, 2.

Putra, Y. P., \& Yuliari, K. (2017). Analisis Unit Cost Mahasiswa Berdasarkan Activity Based Costing (ABC) Pada Fakultas Ekonomi Universitas " $\mathrm{X}$ " di Kota Kediri. Jurnal Nusamba Vol. 2 No. 12017.

Putri, D. A. (2011). Analisis Penggunaan Metode Activity Based Costing Sebagai Alternatif Dalam Menentukan Tarif SPP SMP-SMA pada YPI Nasima Semarang Tahun 2010. Skripsi.

Putri, D. R., Saifi, M., \& Hidayat, R. R. (2016). Penerapan Sistem ABC (Activity Based Costing System) Sebagai Dasar Pembebanan Biaya Overhead Pabrik (Studi Kasus pada PT. Wonojati Wijoyo Kediri Jawa Timur)". Jurnal Administrasi Bisnis (JAB) Vol. 35 No. 1 Juni 2016.

Saputri, E. I. (2020). Analisis Faktor-faktor yang Menyebabkan Penumpukan Pencairan Dana APBN di Akhir Tahun Anggaran pada SAtuan Kerja Lingkup Pembayaran Kantor Pelayanan Perbendaharaan Negara Blitar. Skripsi, 14.

Sukmono, R. (2015). Analisis Dampak Implementasi Indikator Kinerja Utama Terhadap Serapan Anggaran BPPK. InfoArtha ISSN 0852-6737 Volume 1 Tahun XIV / 2016.

Sumarsan, T. (2016). Penetapan Biaya Berdasarkan Aktivitas (Activity Based Costing). Dalam Sistem Pengendalian Manajemen: Konsep, Aplikasi dan Pengukuran Kinerja Edisi 2 (hal. 164-165). Jakarta: PT Indeks.

Supriyono. (2011). Akuntansi Biaya Pengumpulan Biaya dan Penentuan Harga Pokok. Yogyakarta: BPFE.

TN, M. R. (2015). Penerapan Activity Based Costing System Dalam Perhitungan Biaya Pendidikan Dan Pelatihan Pada Balai Diklat Keuangan Medan TA 2014.

Undang-Undang Nomor 17 Tahun 2003 tentang Keuangan Negara

Undang-Undang Nomor 1 Tahun 2004 tentang Perbendaharaan Negara

Undang-Undang No 15 Tahun 2004 tentang Pemeriksaan, Pengelolaan dan Tanggung Jawab Keuangan Negara

Yulianti. (2012). Penerapan Activity Based Costing System Sebagai Dasar Penetapan Tarif Jasa Rawat Inap (Studi Kasus Pada RSUD H. A. Sulthan Daeng Radja Bulukumba. Skripsi.

(C) 2021 by authors. Content on this article is licensed under a Creative Commons Attribution 4.0 International license. (http://creativecommons.org/licenses/by/4.0/). 